\title{
The Dissociation of Morphogenesis from Cell Division in the Cellular Slime Mould, Dictyostelium discoideum
}

\author{
BY RAQUEL R. SUSSMAN AND M. SUSSMAN \\ Brandeis University, Waltham, Massachusetts, U.S.A.
}

(Received 5 April 1960)

\begin{abstract}
SUMMARY
Dictyostelium discoideum, strain Fty-1, myxamoebae were harvested from the stationary phase and dispensed in small population samples on washed agar. Total cell counts were made at intervals between deposition and fruit construction. Within an uncertainty level of $2.5 \%$, the data indicate that the populations remained constant and the terminal fruits contained the same number of cells as had formed the aggregates. Subsidiary evidence based on viability determinations and the known morphology of moribund cells suggested that new cells did not arise nor old cells die.

When myxamoebae were harvested from the log phase while still feeding on a high density of bacteria, a substantial degree of cell division did occur during morphogenesis. But the increase in cell number of myxamoebae which had not aggregated corresponded approximately, with that of myxamoebae which had aggregated and fruited. Consequently such increases appear to be coincidental with and not causally related to the morphogenetic sequence.
\end{abstract}

\section{INTRODUCTION}

Growth and morphogenesis can occur separately in the development of the slime moulds if by growth is meant an increase in protoplasmic mass. This is supported by the following observations. Washed myxamoebae on washed agar gel display the normal morphogenetic pattern (Sussman \& Nöel, 1952). Since effectively no exogenous nutrients are present, a net increase in protoplasmic mass is impossible. Myxamoebae, harvested at any stage of the log phase and washed free of bacterial associates, can aggregate and construct normal fruits without unusual delay (Sussman, 1956). Yet, when left untouched on the growth plate, these myxamoebae would not have begun morphogenesis until the bacterial food supply had been exhausted and the stationary phase attained. The addition of fresh bacteria to myxamoebae which have completed an early stage of the morphogenetic sequence brings about its cessation and their return to the vegetative stage (Raper, 1941).

It had long been assumed that morphogenesis is uncoupled not only from protoplasmic increase but also from cell division (Raper, 1941). Subsequently, however, Bonner \& Frascella (1952) reported mitotic divisions in Dictyostelium discoideum pseudoplasmodia, beginning at the anterior end and proceeding posteriorly in a wave. The peak incidence of metaphase figures was c. $2 \%$ which, because cell division is accomplished rapidly, reflected an appreciable increase in cell number. 
These results suggested the possibility that cell division might play a role more than coincidental in the morphogenetic sequence.Wilson (1952, 1953), Wilson \& Ross (1957) and Ross (1959) also reported division figures during fruit construction by Dictyostelium discoideum and concluded that both meiosis and mitosis occurred and further, that syngamy by cell engulfment occurred immediately before aggregation. The fact, then, that one can actually observe cell division during fruiting has made it important to determine whether there is an obligatory relation between the two. An examination of this question has been carried out with a 'Fruity' mutant of $\boldsymbol{D}$. discoideum, strain Fty-1 (Sussman, 1955). This mutant can form tiny aggregates, composed of very few cells; this made it possible to obtain accurate cell counts at all morphogenetic stages. The results indicate that normal construction can go on without cell division. One can observe considerable increases in cell numbers during aggregation and fruiting by harvesting cells while they still contain a large endogenous supply of bacteria. However, such cells continue to divide independently of whether or not they happen to be engaged in constructing a fruit.

\section{METHODS}

Organism. Dictyostelium discoideum strain Fty-1 was grown on SM agar in association with Aerobacter aerogenes (Sussman, 1951). This strain is a mutant of D. discoideum NC-4, obtained by ultraviolet irradiation. Chromosome counts of preparations fixed by osmium tetroxide, and stained with aceto orcein, showed it to be a stable diploid stock (Ross, 1959). In contrast, the wild type from which it was derived has been found to be haploid. After incubation for 40-44 hr. at $22^{\circ}$, the myxamoebae had attained the stationary phase and were harvested, washed by differential centrifugation and dispensed in drops from a micropipette on to washed water agar gel.

Counting procedures. Two counts were made of each population sample during the pre-aggregative period; precision analysis is given in the next section. After fruiting, the fruits were examined in situ under oil at $\times 950$ magnification to count the spores, stalk- and basal-disk cells (Sussman, 1955). Aggregates had first to be dispersed before cell counts could be made; this was accomplished by trypsinization.

Aggregate dispersal. The trypsinization procedure used was that of Trinkaus \& Groves (1955). A drop of buffered trypsin solution was placed on the aggregated cells. After a few minutes, by which time the excess fluid had been absorbed by the agar, the aggregated myxamoebae were completely dispersed and could be counted precisely.

\section{RESULTS}

\section{The precision of the counting procedure}

Tables 1 and 2 are a summary of the data concerned with the precision of the counting; counts were made immediately after deposition of the cells on washed water agar gel and again after incubation for $3 \mathrm{hr}$. The data from experiment 4-4 are given in Table 1 and summarized with those of three other experiments in Table 2. In experiment 4-4, the mean percentage difference between the successive counts was 0.3 cells/drop or $1.6 \%$. The highest in any of the experiments was $2.3 \%$. 


\section{Cell turnover}

Direct counts can detect only net changes in cell number. Thus, a system in which new cells appeared at an appreciable rate, but old cells died and lysed immediately at the same rate would reflect no change in number. That no such dynamic equilibrium played a part in the experiments to be described is indicated by the following

\section{Table 1. Precision of direct counts}

Myxamoebae were dispensed in microdrops on washed water agar gel. Cell counts were made at $0 \mathrm{hr}$. (A) and again after $3 \mathrm{hr}$. incubation (B).

\section{Experiment 4-4}

Number of cells

\begin{tabular}{|c|c|c|c|}
\hline $\begin{array}{c}\text { A } \\
0 \mathrm{hr} .\end{array}$ & $\begin{array}{c}\text { B } \\
\mathbf{3} \mathrm{hr} .\end{array}$ & B-A & $\begin{array}{c}\text { Difference } \\
\%\end{array}$ \\
\hline 18 & 17 & -1 & $2 \cdot 9$ \\
\hline 18 & 16 & -2 & $5 \cdot 9$ \\
\hline 23 & 23 & 0 & $\mathbf{0}$ \\
\hline 24 & 24 & 0 & 0 \\
\hline 25 & 23 & -2 & $4 \cdot 2$ \\
\hline 30 & 28 & -2 & $3 \cdot 5$ \\
\hline 37 & 39 & 2 & $2 \cdot 6$ \\
\hline 39 & 40 & 1 & $1 \cdot 3$ \\
\hline 48 & 48 & 0 & 0 \\
\hline 51 & 51 & 0 & 0 \\
\hline 51 & 50 & -1 & $1 \cdot 0$ \\
\hline 55 & 55 & 0 & 0 \\
\hline 59 & 56 & -3 & $2 \cdot 6$ \\
\hline 60 & 60 & 0 & o \\
\hline 61 & 64 & 3 & $2 \cdot 4$ \\
\hline 63 & 63 & 0 & 0 \\
\hline 68 & 68 & 0 & 0 \\
\hline
\end{tabular}

Table 2. Determinations of the precision of the cell-count procedure

Data from four separate experiments are summarized, all performed as described in Table 1.

$\begin{array}{ccccc}\text { Experiment } & \text { No. drops } & \begin{array}{c}\text { Mean no. } \\ \text { cells }\end{array} & \begin{array}{c}\text { Smallest and } \\ \text { largest samples }\end{array} & \begin{array}{c}\text { Mean \% } \\ \text { difference }\end{array} \\ 3-5 & 18 & 46 & 30-70 & 2 \cdot 1 \\ 3-12 & 22 & 41 & 30-66 & 0 \cdot 8 \\ 3-20 & 14 & 42 & 16-70 & 2 \cdot 3 \\ 4-4 & 17 & 43 & 18-68 & 1 \cdot 6\end{array}$

observations. Moribund myxamoebae on washed agar did not lyse and disappear immediately. Instead, they swelled to gigantic size, became perfectly smooth in outline and devoid of internal structure. After an hour or so they lysed but ghosts remained in the form of the collapsed cell membranes and granular debris. Thus an appreciable number of cells could not have died, nor new cells have appeared, without making this fact apparent. Since the cells did not lyse immediately, an appreciable death rate, had it existed, should have been detectable by a difference between direct counts and viable counts. To test this, several microdrops were dispensed 
singly, on plates of washed water agar gel and direct counts were made immediately and after incubation for $18 \mathrm{hr}$. Then a few drops of a broth culture of Aerobacter aerogenes were added and the myxamoebae and bacteria distributed over the agar surface with a flamed glass spreader. After 2-3 days, plaques of myxamoebae appeared within the film of bacteria (Sussman, 1951). Table 3 summarizes the data and shows that direct and viable counts were in good agreement. Further, past studies of Dictyostelium discoideum wild type and 'aggregateless' mutants have indicated that myxamoebae can remain $100 \%$ viable and constant in number on washed water agar gel for periods up to $96 \mathrm{hr}$. (Sussman, 1952).

\section{Table 3. Viability determinations}

Cell counts were made within microdrops on washed agar. Then bacteria were added and plaques were allowed to develop and were counted as described in the text.

$\begin{array}{ccc}\begin{array}{c}\text { Cell } \\ \text { count }\end{array} & \begin{array}{c}\text { Plaque } \\ \text { count }\end{array} & \begin{array}{c}\% \\ \text { viability }\end{array} \\ 5 & 5 & 100 \\ 6 & 6 & 100 \\ 6 & 7 & 114 \\ 11 & 11 & 100 \\ 12 & 11 & 91 \\ 13 & 13 & 100 \\ 14 & 14 & 100 \\ 18 & 17 & 94 \\ 21 & 19 & 90 \\ 27 & 26 & 96 \\ 36 & 34 & 94 \\ 54 & 50 & 93 \\ 223 & 213 & 96\end{array}$

Direct counts after aggregation and fruit construction

Microdrops were dispensed on to washed water agar gel. Counts were made immediately and after incubation for $3 \mathrm{hr}$. At 18-24 hr. counts were made of drops which had not aggregated. Simultaneously some aggregated populations were dispersed by trypsinization and counted. Others were allowed to complete construction of the fruiting body and these were counted under oil as previously described. Table 4 gives a summary of the data. As seen, the net changes in cell number were negligible yielding a mean difference of about $2.5 \%$, a value indistinguishable from the fluctuations due to the counting error shown in Table 1. Thus, under these conditions and within the limits of the counting procedure, normal aggregation and fruit construction were completely dissociated from changes in cell number.

The experiment summarized in Table 5 shows that, when the myxamoebae possessed considerable endogenous stores of undigested bacteria, fruit construction was accompanied by considerable cell division. Myxamoebae were harvested from growth plates before all the bacteria had disappeared. The myxamoebae were washed by centrifugation to free them of external bacteria (Sussman, 1952) but microscopic examination revealed the presence of large numbers of undigested intracellular bacteria. Microdrops were dispensed on washed water agar gel. Cell counts were made immediately and after incubation for $18 \mathrm{hr}$. in drops containing no aggregates, and after $30 \mathrm{hr}$. in drops containing aggregates, that is, after terminal 
Dictyostelium discoideum

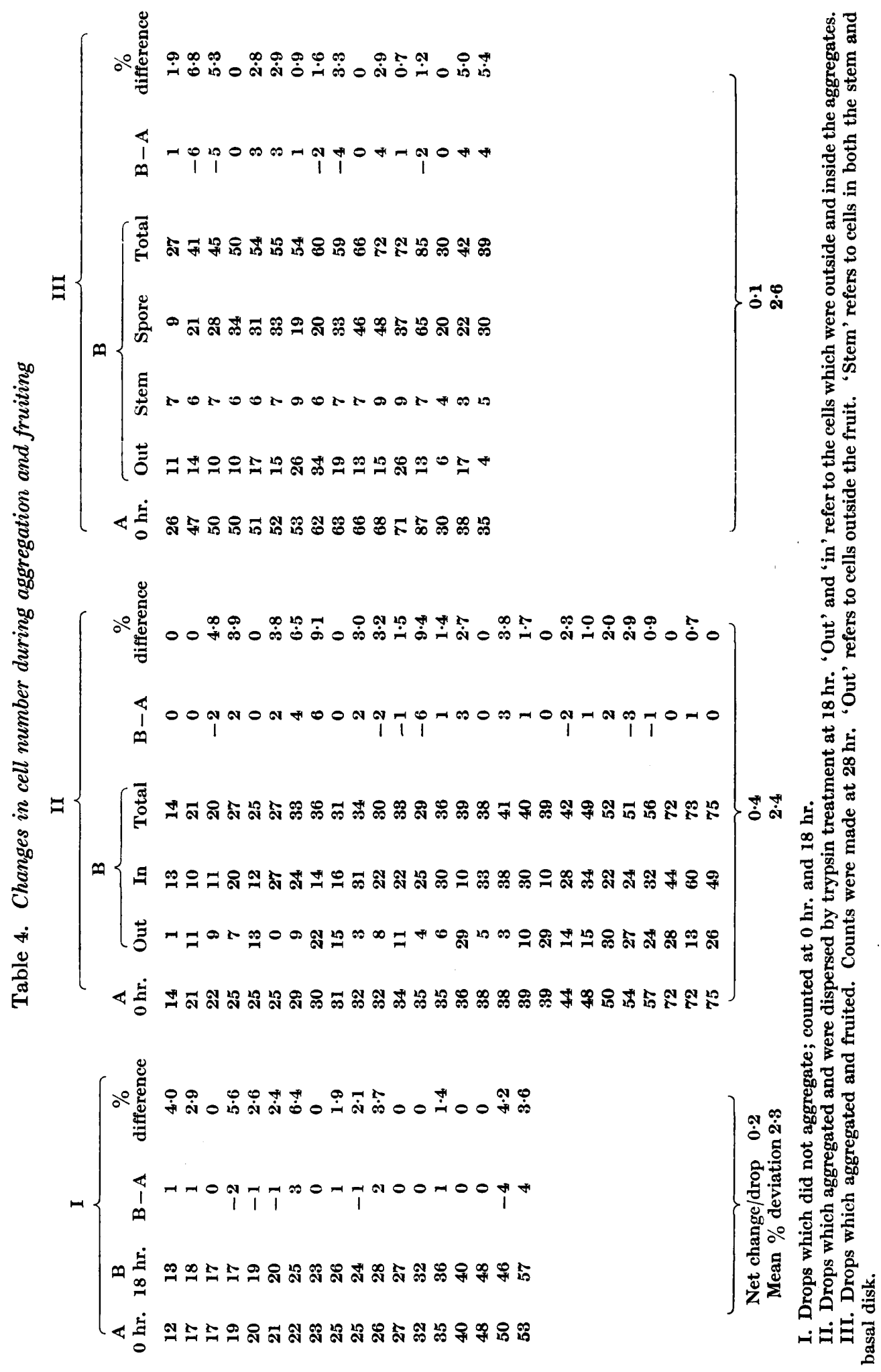


fruits had appeared. In the latter class, an increase of 29 cells/drop was observed for an average of almost $33 \%$. The increase was not as great in drops without aggregates but probably equivalent when it is considered that these counts were made $12 \mathrm{hr}$. earlier. Thus it appears that the cell division here encountered bore no causal relation to the fruiting process but merely reflected the extraordinary endogenous food reserves possessed by the myxamoebae when these are actively

Table 5. Changes in cell number during fruiting

\begin{tabular}{|c|c|c|c|}
\hline $\begin{array}{c}\text { A } \\
0 \mathrm{hr} .\end{array}$ & $\begin{array}{c}\text { B } \\
18 \mathrm{hr} .\end{array}$ & $\mathbf{B}-\mathbf{A}$ & $\begin{array}{c}\% \\
\text { difference }\end{array}$ \\
\hline 16 & 25 & 9 & 22 \\
\hline 21 & 27 & 6 & 12.5 \\
\hline 30 & 54 & 24 & 31 \\
\hline 33 & 4.5 & 12 & $15 \cdot 4$ \\
\hline 37 & 43 & 6 & $7 \cdot 5$ \\
\hline 38 & 54 & 16 & $17 \cdot 4$ \\
\hline 45 & 70 & 25 & $21 \cdot 8$ \\
\hline 46 & 63 & 17 & $15 \cdot 6$ \\
\hline 47 & 59 & 12 & $11 \cdot 3$ \\
\hline 46 & 64 & 18 & $16 \cdot 3$ \\
\hline & an $\%$ & e/dr & $\begin{array}{l}14.5 \\
\quad 17 \cdot 1\end{array}$ \\
\hline
\end{tabular}

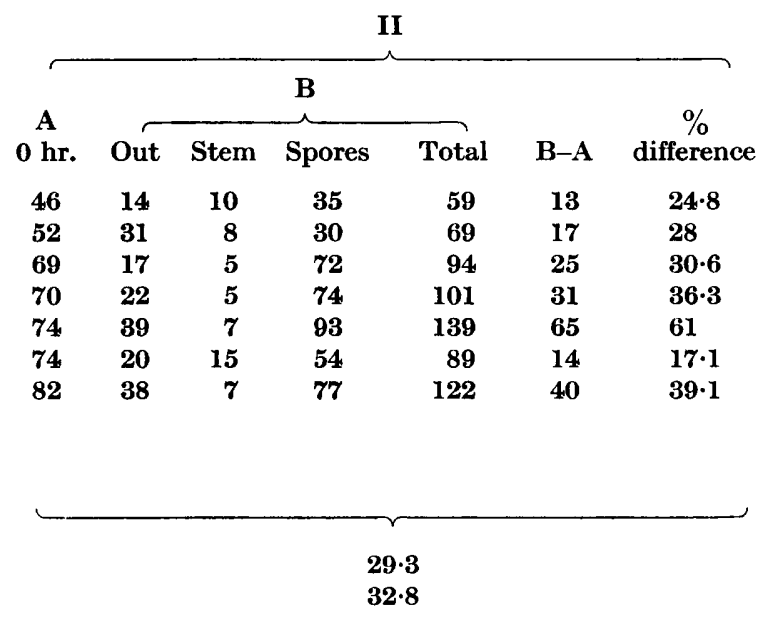

I. Drops which did not aggregate; counts at 0 and $18 \mathrm{hr}$.

II. Drops which fruited. Counts made at 0 and $30 \mathrm{hr}$. 'Out' refers to cells outside the fruit. Stem' refers to both stem and basal disk cells.

feeding upon a dense bacterial population. Had the myxamoebae been allowed to grow upon a less dense bacterial population (Sussman, 1956) or to attain the stationary phase before harvesting so as to deplete the quantity of intracellular undigested bacteria, the extraneous cell division would have been eliminated as it was in the experiments shown in Table 4.

This investigation was supported by grants from The National Institutes of Health and the National Science Foundation.

\section{REFERENCES}

Bonner, J. T. \& Frascella, E. (1952). Mitotic activity in relation to differentiation in D. discoideum. J. exp. Zool. 121, 61.

RAPER, K. B. (1941). Developmental pattern in simple slime molds. Grozeth, 5, 41 .

Ross, I. K. (1959). Diploid strains of Dictyostelium discoideum. Amer. J. Bot. 47, 54.

Sussman, M. (1951). Origin of cellular heterogeneity in the slime molds. J. exp. Zool. 118, 407.

Sussman, M. (1952). Aggregation stage in the development of the slime molds. II. Biol. Bull., Woods Hole, 103, 446.

Sussman, M. (1955). Fruity and other mutants of Dictyostelium discoideum. J. gen. Microbiol. 13, 295.

Sussman, M. (1956). On the relation between growth and morphogenesis in the slime mold, D. discoideum. Biol. Bull., Woods Hole, 110, 91. 
Sussman, M. \& NöEL, E. (1952). Aggregation stage in the development of the slime molds, I. Biol. Bull., Woods Hole, 103, 259.

Sussman, M. (1953). Cytological study of the life cycle of Dictyostelium. Amer. J. Bot. 40, 714.

Trinkaus, J. P. \& Groves, B. (1955). Differentiation in cultures of mixed aggregates of dissociated cells. Proc. Nat. Acad. Sci., Wash. 41, 78.

Wilson, C. M. (1952). Sexuality in the Acrasiales. Proc. Nat. Acad. Sci., Wash. 38, 659.

Wirson, C. M. (1953). Cytological study of the life cycle of Dictyostelium. Amer. J. Bot. 40, 345.

Wilson, C. M. \& Ross, I. K. (1957). Further cytological studies on the Acrasiales. Amer. J. Bot. 44, 345. 